DOI: http://doi.org/10.31617/k.knute.2019-03-19.58

\title{
PR-КАМПАНІЯ ТЕЛЕВІЗІЙНОГО ПРОДУКТУ (СЕРІАЛ «ШКОЛА» ТОВ «ТЕЛЕРАДІОКОМПАНІЯ «СТУДІЯ 1+1»)
}

\author{
Москальчук С. В. \\ ПР-менеджер прес-служби \\ ТОВ «Телерадіокомпанія «Студія $1+1 »$ \\ Бучацька I. O. \\ к.е.н., доцент \\ кафедра журналістики та реклами \\ Київський національний торговельно-економічний університет, \\ Украӥна
}

Ключові слова: телевізійний продукт, телебачення (ТБ), ПРкампанія, медіа.

Keywords: television product, television (TV), PR-campaign, media.

Кожен 3МІ має власну цільову аудиторія і в залежності від іiі потреб - виробляє продукт. У онлайн - ЗМІ - це спецпроекти, інтерв'ю, газети та журнали у відповідності до своєї цільової аудиторії (ЦА) обирають обличчя на обкладинку та публікують інтерв'ю, а телебачення - створюють програми та серіали - телевізійні продукти.

Тенденція розвитку рекламного ринку в Україні і у світі дає змогу стверджувати, що інтенсивно йде перерозподіл між основними засобами 3МІ і зменшується частка телебачення, оскільки його цільова аудиторія старіє, а молодь переглядає контент лише у Інтеренеті. Але, по-перше, якщо глобальніше поглянути на речі, то близько $40 \%$ населення України немає доступу до Інтернету. По-друге, прогресивні телекомпанії вже починають адаптуватися до змін, які беззаперечно настануть і починають активну роботу над виробленням телевізійних продуктів для залучення більш молодої аудиторії до перегляду. Одним із найуспішніших прикладів залучення молодої аудиторії до перегляду телевізійного продукту став серіал «Школа» ТОВ «Телерадіокомпанії «Студія 1+1».

«Школа» - перший україномовний серіал, який розповідає про реалії життя школярів та їх стосунків із викладачами та батьками. Стрічка «Школа» стала найрейтинговішим серіалом на українському телебаченні (ТБ) у сезоні осінь 2017 р. - зима 2018 р. по аудиторії 18-54 (Україна). Найвищого рейтингу 6,9\% за переглядом визнана 8-ма серія. Середня частка за перші 4 тижні показу становила 15,8\% 
по аудиторії 18-54 (Україна) та 12,1\% - по 18-54 (50К+). Середня аудиторія однієї серії склала близько 2 млн глядачів, а загальне охоплення за 4 тижні перевищило 18,5 м глядачів (4+, Україна).

Цільова аудиторія телеканалу - це дорослі жінки, які мають дітей-школярів, які через завантаження на роботі, часто не мають змоги повноцінно впливати на їхнє виховання. Для того, щоб показати дорослим реальні проблеми власних дітей і те, які наслідки вони можуть мати - телеканал «1+1» створив україномовний серіал «Школа», заснованих на реальних подіях.

У центрі серіалу - пара молодих викладачів, які випадково потрапили на роботу до однієї з українських шкіл та намагаються вирішити проблеми учнів. Головна героїня Катя, яку грає акторка Яна Андрєєва, - успішна бізнес-леді, чия донька переживає кризу підліткового віку. Саме заради доньки Яна йде працювати до школи вчителькою економіки. У цей час до навчального закладу також приходить новий викладач англійської, колишній адвокат Алекс, роль якого виконує Микита Вакулюк. У Алекса є наречена, яка живе у США, у той же час між ним та Катериною спалахують нові почуття.

Автори серіалу «Школа» багато уваги приділяють актуальним проблемам школярів, з якими вони стикаються під час підліткового періоду: «буллінг» однолітків, нерозуміння в родині, хабарі вчителям та інтриги. Діти в серіалі - типові українські школярі, які дорослішають, зустрічаються 3 викликами на новому етапі життя та намагаються знайти відповіді на запитання: як стати популярним, як завоювати повагу однокласників, як побудувати стосунки з батьками.

Прем'єра стрічки відбулася взимку 2018 року і після виходу перших серій зібрала рекордні показники перегляду як в Інтернеті, так і на телебаченні, а актори - стали улюбленцями мільйонів.

ПР-кампанія продукту була вибудувана таким чином, щоб через підлітків до перегляду серіалу привести дорослу аудиторію. Це було реалізовано завдяки: позиціонуванню продукту, відсутності конкурентів у ніші серіалів для підлітків на українському телебаченні та низькому рівні перегляду передач телеглядачами в телесезоні (лютий).

Окрім стандартних ПР-активностей: публікації, обкладинки, інтерв'ю, сюжети, прес-виїзди на знімальні майданчики, команда проекту також розробила ПР-кампанію у діджиталі, організувала наймасштабнішу фан-зустріч на 9 тис. глядачів з акторами у столичному ТРЦ та видала книгу за мотивами стрічки.

Серіал «Школа» виробництва «1+1 Продакшн» був представлений на найбільшій європейській щорічній виставці аудіовізуального контенту MIPTV-2018 у французькому місті Канни. Стрічка була 
показана в рамках програми «Fresh Fiction around the world», де презентують найбільш інноваційні, креативні та успішні серіали з усього світу.

Україномовний телевізійний продукт викликав неабиякий інтерес світової телевізійної спільноти, після чого за перші кілька днів виставки три телекомпанії виявили бажання придбати формат.

Отже, серіал «Школа» є яскравим прикладам того, що сучасний глядач готовий сприймати телевізійний продукт не залежно від віку. Історія просування бренду «Школа» розпочалася ще до виходу першого сезону серіалу в ефір. Маркетологи розробили окрему промокампанію для підлітків, на яких тестували контент. Якщо реклама для дорослих розповсюджувалася на телебаченні та у соціальній мережі Facebook, то для молодої аудиторії - в YouTube, Instagram і на радіо.

Основною комунікаційною платформою було обрано Instagram, де почала формуватися спільнота прихильників (фанів) серіалу. До рекламування серіалу «Школа» залучили популярних серед підлітків блогерів та лідерів думок серед школярів. У день прем'єри першого сезону активна аудиторія налічувала 170 тис. сіоб тільки в Instagram.

Далі створювався та розповсюджувався спеціальний контент саундтрек, караоке до саундтреку, гра у Viber, стікери, постери, відео, спеціальний сайт для фанів. Також проводилися фан-зустрічі в різних містах України з акторами та основним складом команди знімального процесу. На цих заходах дизайнери проекту вивчали, який одяг носять та які мають аксесуари представники цільової аудиторії, та розробляли спеціальні брендовані товари для продажу.

Варто зрозуміти кожному маркетологу та фахівцю у сефрі комунікацій, що створюючи продукт необхідно відразу проектувати його просування на всі майданчики для різних цільових аудиторій. Адже одну групу людей, можна охопити через іншу, враховуючи різні критерії впливу.

\section{Список використаних джерел}

1. Серіал «Школа» : офіційний сайт. - Режим доступу : https://1plus1.ua/ru/shkola

2. Головні герої серіалу «Школа» розповіли про інтриги другого сезону стрічки 1+1. - Режим доступу : https://1plus1.ua/shkola/ novyny/golovni-geroi-serialu-skola-rozpovili-pro-intrigi-drugogosezonu-stricki 27.08.2018. Архів оригіналу за 28.08.2018. Процитовано 27.08.2018. 